\title{
Enterohormonal disturbances in colorectal cancer patients
}

\author{
A. L. ZYGULSKA ${ }^{1, *}$, A. FURGALA², K. KRZEMIENIECKI ${ }^{3}$, J. KASZUBA-ZWOINSKA², P. THOR²
}

${ }^{1}$ Department of Oncology, Krakow University Hospital, 10 Sniadeckich St., 31-531 Krakow, Poland; ${ }^{2}$ Department of Pathophysiology Medical College Jagiellonian University, 18 Czysta St., 31-121 Krakow, Poland; ${ }^{3}$ Department of Oncology, Jagiellonian University, 10 Sniadeckich St., 31-531 Krakow, Poland

*Correspondence: zygulska@poczta.onet.pl

Received September 4, 2016/ Accepted October 27, 2016

\begin{abstract}
Gastrointestinal (GI) hormonal peptides play a role in the development of gastrointestinal malignancies, and their abnormal levels may contribute to dysmotility. The aim of this study was to analyze plasma concentrations of enterohormones (motilin, ghrelin, gastrin and pancreatic polypeptide) and to verify if their abnormal levels may contribute to the severity of dyspeptic symptoms in colorectal cancer patients. The study included 60 patients with colorectal malignancies (22 men and 38 women), among them 30 individuals with colon cancers (group A) and 30 subjects with rectal tumors (group B). Fasting plasma levels of pancreatic polypeptide (PP), motilin, gastrin and ghrelin were determined by means of ELISA. The results were compared with the respective parameters of healthy volunteers. Colon cancer patients presented with significantly lower concentrations of ghrelin than the subjects with rectal tumors and healthy controls ( $156.8 \pm 86.7$ vs. $260.2 \pm 87.6 \mathrm{vs} .258 .4 \pm 94.2 \mathrm{pg} / \mathrm{ml}$, $\mathrm{p}=0.02)$, as well as with significantly higher levels of $\mathrm{PP}(265.5 \pm 66.3 \mathrm{vs} .154 .1 \pm 54.6$ vs. $148.3 \pm 64.3 \mathrm{pg} / \mathrm{ml}, \mathrm{p}=0.005)$. Also the levels of motilin turned out to be lower in colon cancer patients than in the subjects with rectal malignancies and healthy controls. No statistically significant intergroups differences were found in plasma levels of gastrin (388.2 \pm 98.6 vs. $475.6 \pm 88.7$ vs. $428.2 \pm 91.2 \mathrm{pg} / \mathrm{ml}, \mathrm{p}>0.05)$. Epigastric bloating was the most frequent dyspeptic symptom, reported by $63.3 \%$ and $40 \%$ of patients with colon and rectal tumors, respectively. Our findings imply that colon cancer patients may present with abnormal plasma levels of enterohormones significantly more often than individuals with rectal malignancies. Dysmotility observed in colon cancer patients may result not only from anticancer surgery, but also from abnormal release of enterohormones, induced either by neoplastic process or by changes within the autonomic nervous system.
\end{abstract}

Key words: motilin, ghrelin, gastrin, pancreatic polypeptide, colorectal cancer

Synthesis of hormones is a physiological albeit sometimes neglected function of the gastrointestinal tract. Enterohormones modulate gastrointestinal motility and mucosal growth, regulate metabolism of glucose and play immune functions. Principal function of motilin is stimulation of gastrointestinal motility during fasting [1-5]. Moreover, this hormone promotes gallbladder motility and the release of bile into the duodenum [6]. Pancreatic polypeptide controls exocrine function of the pancreas [7] in response to hunger and satiety signaling from the gut-brain axis [8], and reduces gastric emptying [8]. Ghrelin contributes to gastrointestinal motility, regulation of appetite, response to hunger and starvation [3, 9-19], and inhibits nausea [18]. Gastrin controls release of histamine, a compound stimulating gastric cells to hydrochloric acid secretion, promotes cell migration, invasion, apoptosis, tubulogenesis and angiogenesis [20-23].
Aside from their physiological functions mentioned above, enterohormones may also play a role in the development of gastrointestinal malignancies. Motilin seems to contribute to anticancer chemotherapy-associated dyspepsia syndrome. Low plasma levels of this hormone in breast cancer patients receiving FEC chemotherapy coexisted with an impairment of gastrointestinal motility [24]. Plasma concentration of motilin in gastric cancer patients decreased significantly on the first post-gastrectomy or post-subtotal-gastrectomy day, and then normalized at its preoperative level within the next seven days $[25,26]$. In turn, patients with metastatic gastroenteropancreatic neuroendocrine tumors (GEPNETs) presented with elevated levels of pancreatic polypeptide [27].

Various tumors express ghrelin and its receptor (GHS-R); expression of ghrelin, at both mRNA and protein level, was found in gastrointestinal neuroendocrine tumors (NETs), 
gastroenteropancreatic carcinoids, colorectal cancers and pancreatic carcinomas $[16,28]$. This implies that this enterohormone may play an autocrine/paracrine function in neoplastic cell growth. Indeed, many studies revealed that ghrelin contributes to proliferation, differentiation and invasiveness of cancer cells, and protects them against apoptosis $[13,17,19,28]$. Also suppression of fasting ghrelin in gastric cancer patients points to potential involvement of this hormone in carcinogenesis [29].

Most colorectal malignancies synthesize gastrin which acts in an autocrine manner [31-33]. Non-amidated gastrin was shown to stimulate mucosal cell growth at early stages of colorectal carcinogenesis [34]. Elevated plasma concentrations of this hormone were also documented in gastric cancer patients $[23,24,35]$. Fossman et al. demonstrated that in patients with hypergastrinemia, gastric adenocarcinomas were located in the gastric corpus more frequently than in normogastrinemic subjects. Furthermore, hypergastrinemia correlated with shorter survival in advanced (stage II-IV) gastric cancer [36]. Elevated levels of gastrin seem to be also associated with pancreatic cancer risk [21]. Bombski et al. observed a significant positive correlation between plasma gastrin, CEA and colorectal cancer stage [37]. On the other hand, Selgard et al. [38] and Lamberts et al. [39] did not find a link between hypergastrinemia and colorectal cancer risk. According to Niv et al., concentrations of gastrin in arterial and venous blood draining colorectal

Table 1. Basic characteristics of colon cancer patients (group A).

\begin{tabular}{|c|c|}
\hline Parameter & $\mathbf{n}=\mathbf{3 0}$ \\
\hline sex & $\mathrm{M}: \mathrm{F}=8(26.7 \%): 22(73.3 \%)$ \\
\hline $\begin{array}{l}\text { median age } \\
\text { (range) }\end{array}$ & 64.8 years $(40-85)$ \\
\hline $\begin{array}{l}\text { type of } \\
\text { surgical } \\
\text { treatment }\end{array}$ & $\begin{array}{l}\text { hemicolectomy - } 15(50 \%) \\
\text { resection of the colon }-7(23.3 \%) \\
\text { abdominoperineal amputation of the rectum - } 1(3.3 \%) \\
\text { abdominoperineal amputation of the rectum, sigmoidectomy } \\
\text { with metastasectomy - } 2(6.7 \%) \\
\text { abdominoperineal amputation of the rectum and resection } \\
\text { of recurrence - } 1(3.3 \%) \\
\text { anterior resection of the rectum }-1(3.3 \%) \\
\text { hemicolectomy and anterior resection of the rectum }-1(3.3 \%) \\
\text { anterior resection of the rectum and sigmoidectomy }-1(3.3 \%) \\
\text { anterior resection of the rectum and metastasectomy }-1(3.3 \%)\end{array}$ \\
\hline $\begin{array}{l}\text { surgical } \\
\text { treatment }\end{array}$ & radical - $23(76.7 \%)$ palliative $-7(23.3 \%)$ \\
\hline chemotherapy & $\begin{array}{l}\text { YES - } 17(56.7 \%) \mathrm{NO}-12(40 \%) \\
\text { hypothermic intraperitoneal chemotherapy (HIPEC) }-1(3.3 \%)\end{array}$ \\
\hline $\begin{array}{l}\text { present } \\
\text { symptoms }\end{array}$ & $\begin{array}{l}\text { symptoms of any type }-23(76.6 \%) \\
\text { diarrhea }-2(6.7 \%) \\
\text { constipation }-2(6.7 \%) \\
\text { fatigue }-2(6.7 \%) \\
\text { heartburn }-1(3.3 \%)\end{array}$ \\
\hline $\begin{array}{l}\text { CEA level } \\
\text { after surgical } \\
\text { treatment }\end{array}$ & $\begin{array}{l}\text { normal - } 23(76.7 \%) \\
\text { abnormal - } 7(23.3 \%) \\
\text { mean level - } 82.86 \pm 73.55 \mathrm{ng} / \mathrm{ml}\end{array}$ \\
\hline
\end{tabular}

malignancies are similar, and do not differ from those found in normal large intestinal mucosa. The same authors did not demonstrate significant differences in gastrin levels within peripheral venous blood of colorectal cancer patients and healthy controls [40].

Although the role of enterohormones in gastrointestinal carcinogenesis seems to be well-established, still many important questions need to be answered. To the best of our knowledge, an association between pancreatic polypeptide concentration and natural history of colorectal cancer has not been analyzed thus far, and only few authors studied the levels of motilin and ghrelin in patients with this malignancy. Also the role of gastrin in colorectal carcinogenesis still raises many controversies. In view of this incomplete evidence, we decided to explore a link between enterohormones and colorectal cancer. In this paper, we present our observations on plasma levels of ghrelin, motilin, gastrin and pancreatic polypeptide in colorectal cancer patients. The aim of the study was to determine plasma levels of motilin, ghrelin, gastrin and pancreatic polypeptide in colorectal cancer patients and correlation with dyspeptic symptoms.

\section{Patients and methods}

The study included 60 patients (22 men and 38 women) recruited at the Department of Oncology, University Hospital in Krakow (Poland) between September 2014 and September 2015. The subjects were divided into two subgroups, with colon cancers (group A, $\mathrm{n}=30,8$ men and 22 women, mean age $64.8 \pm 10.2$ years) and with rectal malignancies (group $\mathrm{B}, \mathrm{n}=30,14$ men and 16 women, mean age $61.2 \pm 9.7$ years). Plasma concentrations of enterohormones determined in these two subsets were compared with the results of healthy asymptomatic controls $(n=30,9$ men and 21 women, mean age $56.2 \pm 12$ years). All experiments were conducted at the Department of Oncology, University Hospital in Krakow (Poland) and at the Department of Pathophysiology, Jagiellonian University Medical College in Krakow (Poland). Protocol of the study was approved by the Local Bioethics Committee at the Jagiellonin University, Medical College in Krakow (decision no. KBET/98/B/2014).

Only the patients who satisfied the following inclusion criteria were enrolled: 1) histologically confirmed colorectal cancer, 2) surgical resection of the colorectal tumor, 3) age $\geq 18$ years, 4) Eastern Cooperative Oncology Group (ECOG) performance status 1 or 0,5 ) no signs and symptoms of neoplastic cachexia, and 6) signed informed consent.

Characteristics of the study subjects, stratified according to cancer location, are presented in Tables 1 and 2.

A 15-ml blood sample was collected from each study subject to determine plasma concentrations of motilin, ghrelin, gastrin and pancreatic polypeptide by means of ELISA. Moreover, all participants completed a survey on the presence and severity of dyspeptic symptoms. The results of the survey, stratified according to cancer location, are shown in Table 3. 
Table 2. Basic characteristics of rectal cancer patients (group B).

\begin{tabular}{|c|c|}
\hline $\begin{array}{l}\text { Rectal cancer patients' } \\
\text { characteristics }\end{array}$ & $\mathrm{n}=\mathbf{3 0}$ \\
\hline sex & $\mathrm{M}: \mathrm{F}=14(46.7 \%): 16(53.3 \%)$ \\
\hline median age (range) & 61.2 years $(43-76)$ \\
\hline $\begin{array}{l}\text { type of surgical } \\
\text { treatment }\end{array}$ & $\begin{array}{l}\text { anterior resection of the rectum - } 17(56.7 \%) \\
\text { abdominoperineal amputation of the rectum - } 10 \\
(33.3 \%) \\
\text { proctocolectomy and partial resection of the ileum } \\
-1(3.3 \%) \\
\text { TEM (transendoscopic microsurgery) with metas- } \\
\text { tasectomy - } 1(3.3 \%) \\
\text { anterior resection of the rectum with metastasectomy } \\
-1(3.3 \%)\end{array}$ \\
\hline surgical treatment & radical - $25(83.3 \%)$ paliative $-5(16.7 \%)$ \\
\hline radiotherapy & YES - $21(70 \%) \mathrm{NO}-9(30 \%)$ \\
\hline chemotherapy & $\begin{array}{l}\text { YES - } 22(73.3 \%) \mathrm{NO}-7(23.3 \%) \\
\text { transcatheter arterial chemoembolization (TACE) } \\
-1(3.3 \%)\end{array}$ \\
\hline present symptoms & $\begin{array}{l}\text { any symptoms - } 27(90 \%) \\
\text { abdominal pain }-1(3.3 \%) \\
\text { bloating }-1(3.3 \%) \\
\text { fatigue and abdominal pain }-1(3.3 \%)\end{array}$ \\
\hline $\begin{array}{l}\text { CEA level after } \\
\text { surgical treatment }\end{array}$ & $\begin{array}{l}\text { normal }-27(90 \%) \\
\text { abnormal }-3(10 \%) \\
\text { mean: } 9.3 \pm 33.8 \mathrm{ng} / \mathrm{ml}\end{array}$ \\
\hline
\end{tabular}

Biochemical assays. Fasting plasma concentrations of ghrelin, pancreatic polypeptide (PP), gastrin and motilin were determined at rest. Blood samples were stored at $2-8^{\circ} \mathrm{C}$ for up to $2 \mathrm{~h}$ after collection. Then, the material was centrifuged at $3800 \mathrm{xg}$ for $10 \mathrm{~min}\left(8^{\circ} \mathrm{C}\right)$ to separate plasma, and aspirated supernatant was stored at $-20^{\circ} \mathrm{C}$ until the analysis (for $6 \mathrm{~h}$ to 1 month).

Fasting plasma concentrations of enterohormones were determined immunoenzymatically with commercially available kits for automated systems: Human (Active) Ghrelin ELISA kit (Demeditec Diagnostic GmbH, Germany) for ghrelin, Human Pancreatic Polypeptide ELISA kit (EMD Millipore Corporation, USA) for pancreatic polypeptide, Gastrin I (G17) Human (Demeditec Diagnostic GmbH, Germany) for gastrin, and Pre-Motilin ELISA kit (Phoenix Europe GmbH, Germany) for motilin, all used in line with their manufacturers' instructions. The sensitivity of the assays was $25 \mathrm{pg} / \mathrm{ml}$ for ghrelin, $12.3 \mathrm{pg} / \mathrm{ml}$ for pancreatic peptide and $0.7 \mathrm{pg} / \mathrm{ml}$ for gastrin and motilin.

Prevalence and severity of dyspeptic symptoms. All patients completed a self-administered survey on subjective presence and severity of ten dyspeptic symptoms: epigastric pain, abdominal discomfort, early fullness, vomiting, nausea, regurgitation, heartburn, epigastric bloating, feeling of food retention in the stomach, early satiety, and loss of appetite (Supplementary file 1 ). The severity of each symptom was scored from 0 to 5 points $(0$ - absent, 1 - incidental, 2 - rare, 3 - frequent, 4 - very frequent, 5 - persistent).
Table 3. The evaluation of intensification dyspeptic symptoms on the basis of the questionnaire of dyspeptic symptoms in colon $(n=30)$ and rectal cancer patients $(n=30)$.

\begin{tabular}{|c|c|c|}
\hline Symptom & Group A $(n=30)$ & Group B $(n=30)$ \\
\hline epigastralgia & $\begin{array}{l}\text { no - } 22(73.3 \%) \\
\text { incidental }-2(6.7 \%) \\
\text { seldom - } 2(6.7 \%) \\
\text { often - } 3(10 \%) \\
\text { almost always - } 1(3.3 \%)\end{array}$ & $\begin{array}{l}\text { no }-24(80 \%) \\
\text { incidental - 3 }(10 \%) \\
\text { seldom - } 2(6.7 \%) \\
\text { often - } 1(3.3 \%)\end{array}$ \\
\hline $\begin{array}{l}\text { a painful sensation of } \\
\text { epigastric region }\end{array}$ & $\begin{array}{l}\text { no - } 14(46.7 \%) \\
\text { incidental - } 2(6.7 \%) \\
\text { seldom - } 9(30 \%) \\
\text { often - 3 }(10 \%) \\
\text { almost always - } 1(3.3 \%) \\
\text { constant - } 1(3.3 \%)\end{array}$ & $\begin{array}{l}\text { no }-24(80 \%) \\
\text { incidental }-1(3.3 \%) \\
\text { seldom - } 3(10 \%) \\
\text { often - } 1(3.3 \%) \\
\text { constant - } 1(3.3 \%)\end{array}$ \\
\hline heartburn & $\begin{array}{l}\text { no }-16(53.3 \%) \\
\text { incidental }-3(10 \%) \\
\text { seldom - } 9(30 \%) \\
\text { often - } 2(6.7 \%)\end{array}$ & $\begin{array}{l}\text { no }-21(70 \%) \\
\text { incidental }-5(16.7 \%) \\
\text { seldom }-4(13.3 \%)\end{array}$ \\
\hline food regurgitation & $\begin{array}{l}\text { no }-26(86.7 \%) \\
\text { incidental }-2(6.7 \%) \\
\text { seldom - } 1(3.3 \%) \\
\text { often - } 1(3.3 \%)\end{array}$ & $\begin{array}{l}\text { no }-29(96.7 \%) \\
\text { incidental - } 1(3.3 \%)\end{array}$ \\
\hline $\begin{array}{l}\text { early feeling of } \\
\text { satiety }\end{array}$ & $\begin{array}{l}\text { no }-22(73.3 \%) \\
\text { incidental }-2(6.7 \%) \\
\text { seldom }-4(13.3 \%) \\
\text { often - } 1(3.3 \%) \\
\text { almost always - } 1(3.3 \%)\end{array}$ & $\begin{array}{l}\text { no }-28(93.3 \%) \\
\text { seldom }-2(6.7 \%)\end{array}$ \\
\hline $\begin{array}{l}\text { feeling of food } \\
\text { retention in stom- } \\
\text { ach }\end{array}$ & $\begin{array}{l}\text { no - } 17(56.7 \%) \\
\text { incidental }-5(16.7 \%) \\
\text { seldom - } 4(13.3 \%) \\
\text { often - } 3(10 \%) \\
\text { almost always - } 1(3.3 \%)\end{array}$ & $\begin{array}{l}\text { no }-25(83.3 \%) \\
\text { incidental - } 2(6.7 \%) \\
\text { seldom - } 3(10 \%)\end{array}$ \\
\hline $\begin{array}{l}\text { bloating in epigastric } \\
\text { region }\end{array}$ & $\begin{array}{l}\text { no - } 11(36.7 \%) \\
\text { incidental - } 5(16.7 \%) \\
\text { seldom - } 9(30 \%) \\
\text { often - } 2(6.7 \%) \\
\text { almost always - } 1(3.3 \%) \\
\text { constant - } 2(6.7 \%)\end{array}$ & $\begin{array}{l}\text { no - } 18(60 \%) \\
\text { incidental }-4(13.3 \%) \\
\text { seldom - } 6(20 \%) \\
\text { often - } 1(3.3 \%) \\
\text { almost always - } 1(3.3 \%)\end{array}$ \\
\hline nausea & $\begin{array}{l}\text { no }-21(70 \%) \\
\text { incidental }-4(13.3 \%) \\
\text { seldom - } 4(13.3 \%) \\
\text { often - } 1(3.3 \%)\end{array}$ & $\begin{array}{l}\text { no }-28(93.3 \%) \\
\text { incidental - } 1(3.3 \%) \\
\text { seldom - } 1(3.3 \%)\end{array}$ \\
\hline vomiting & $\begin{array}{l}\text { no- } 27(90 \%) \\
\text { incidental - } 1(3.3 \%) \\
\text { often - } 2(6.7 \%)\end{array}$ & no- $30(100 \%)$ \\
\hline loss of appetite & $\begin{array}{l}\text { no - } 23(76.7 \%) \\
\text { incidental }-4(13.3 \%) \\
\text { seldom - } 2(6.7 \%) \\
\text { often - } 1(3.3 \%)\end{array}$ & $\begin{array}{l}\text { no }-26(86.7 \%) \\
\text { incidental }-2(6.7 \%) \\
\text { seldom - } 1(3.3 \%) \\
\text { often - } 1(3.3 \%)\end{array}$ \\
\hline
\end{tabular}

Statistical analysis. Statistica 10.0 PL package (StatSoft Inc., Tulsa, OK, USA), licensed for the Jagiellonian University in Krakow, was used for database management and statistical analyses. The results are presented as percentages for discrete variables or means and standard deviations (SD) for continuous variables. Normal distribution of continuous variables was verified with Shapiro-Wilk test. Variables that 


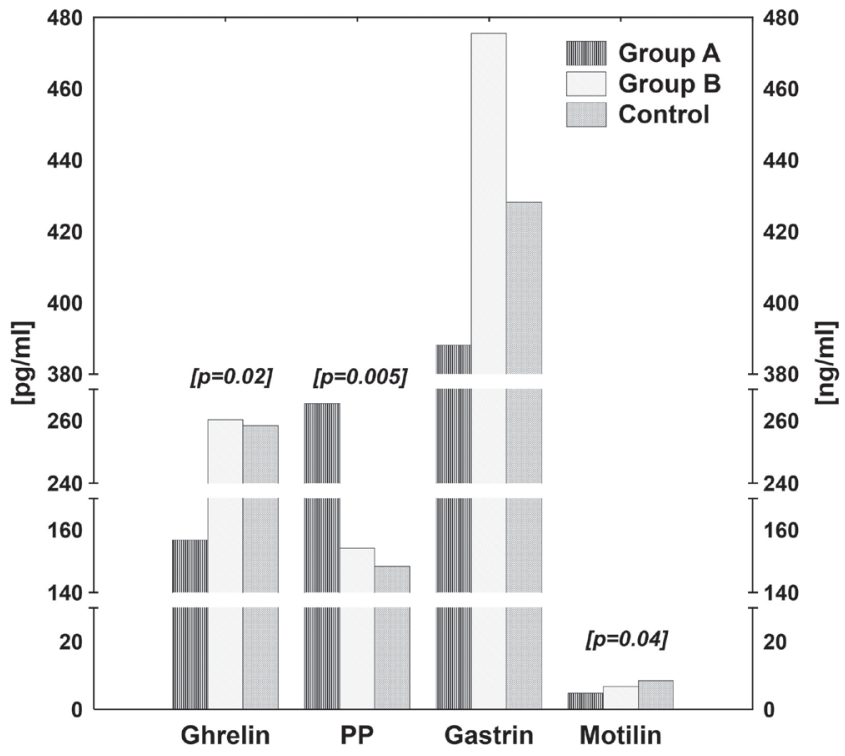

Figure 1. The differences between plasma levels of enterohormones in group A,B and the control.

did not satisfy criteria for normality were subjected to the log-normal transformation prior to further analyses. Intragroup comparisons of quantitative variables with normal and non-normal distributions were conducted with paired Student t-test and Wilcoxon signed rank test, respectively, and intergroup comparisons were carried out with Student t-test for independent variables and Mann-Whitney U-test, respectively. Power and direction of associations between the plasma levels of enterohormones and the severity of dyspeptic symptoms were analyzed on the basis of Spearman's coefficients of rank correlation. Results of all tests were considered significant at $\mathrm{p}<0.05$.

\section{Results}

Plasma concentrations of enterohormones. Colon cancer patients presented with significantly lower fasting plasma concentrations of ghrelin than individuals with rectal malignancies and healthy controls ( $156.8 \pm 86.7$ vs. $260.2 \pm 87.6$ vs. $258.4 \pm 94.2 \mathrm{pg} / \mathrm{ml}, \mathrm{p}=0.02$ ), as well as with significantly higher levels of PP than individuals from the remaining two groups ( $265.5 \pm 66.3$ vs. $154.1 \pm 54.6$ vs. $148.3 \pm 64.3 \mathrm{pg} / \mathrm{ml}, \mathrm{p}=0.005)$. No statistically significant intergroup differences were found in plasma levels of gastrin (388.2 \pm 98.6 vs. $475.6 \pm 88.7$ vs. $428.2 \pm 91.2 \mathrm{pg} / \mathrm{ml}, \mathrm{p}>0.05)$. Mean fasting plasma concentration of motilin in colon cancer patients turned out to be significantly lower than in individuals with rectal malignancies and healthy controls ( $4.8 \pm 2.6$ vs. $6.7 \pm 3.7$ vs. $8.4 \pm 4.1 \mathrm{ng} /$ $\mathrm{ml}, \mathrm{p}=0.04)$. The results are presented on Figure 1. Analysis of enterohormones plasma levels between subgroups of radical and palliative surgery did not show statistical differences.
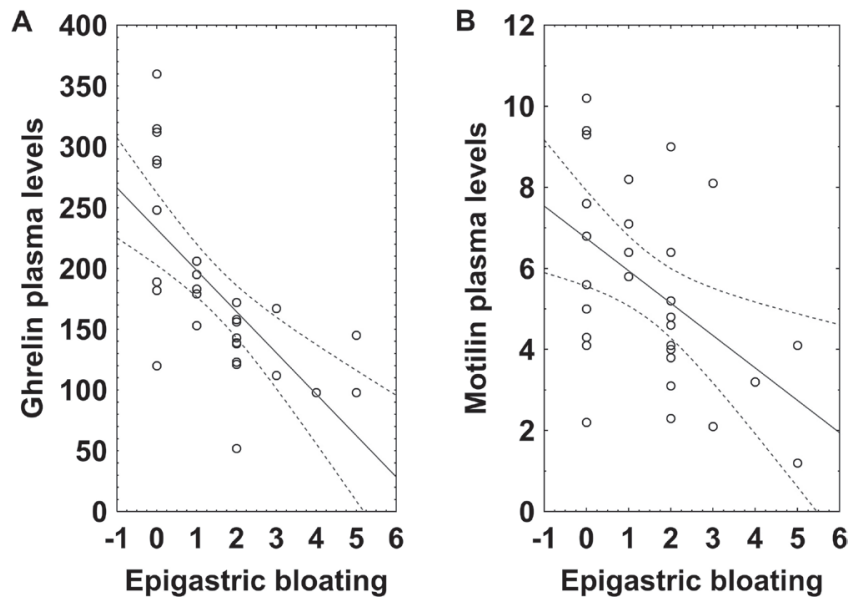

Figure 2. The correlation between epigastric bloating and ghrelin plasma levels (part A) and motilin plasma levels (part B) in patients with colonic (Group A) malignancies.

A small number of patients in each group could result in the lack of differences.

Prevalence and severity of dyspeptic symptoms. Most colorectal cancer patients did not report any dyspeptic symptoms. The most commonly reported ailment was epigastric bloating, present in $63.3 \%$ and $40 \%$ of colon and rectal cancer patients, respectively. In turn, vomiting was of extremely rare evidence among the study subjects, occurring in $10 \%$ of individuals from group $\mathrm{A}$ and in none from group $\mathrm{B}$.

The most severe dyspeptic symptom reported by patients from group A was abdominal discomfort followed by bloating and epigastric pain. In turn, subjects from group B pointed to epigastric bloating as the most burdensome manifestation, but the prevalence of dyspeptic symptoms in this group was generally very low (Table 3 ).

Correlations. Fasting plasma concentrations of ghrelin and motilin correlated inversely with the severity of epigastric bloating in patients from group $\mathrm{A}(\mathrm{r}=-0.66, \mathrm{p}=0.04$, and $\mathrm{r}=-$ $0.48, \mathrm{p}=0.02$, respectively). (Figure 2 ) Furthermore, a positive correlation was found in this group between the plasma concentration of gastrin and the severity of abdominal discomfort $(\mathrm{r}=0.47, \mathrm{p}=0.039)$. No statistically significant correlations between the plasma concentrations of enterohormones and the severity of dyspeptic symptoms were observed in patients from group $\mathrm{B}$.

\section{Discussion}

Under physiological conditions, enterohormones play a pivotal role in the regulation of gastrointestinal motility. However, little is known about the changes in plasma concentrations of gastrin, ghrelin, motilin and PP taking place in colorectal cancer patients. In this study, we analyzed associations between the plasma levels of enterohormones and the 
severity of dyspeptic symptoms in colorectal cancer patients. The main findings can be summarized as follows:

1. Colon cancer patients presented with significantly lower fasting plasma concentrations of ghrelin and motilin than individuals with rectal malignancies and healthy asymptomatic controls, as well as with significantly higher plasma levels of PP. The study groups did not differ significantly in terms of their plasma levels of gastrin.

2. Most colorectal cancer patients did not report any dyspeptic symptoms. The most commonly reported ailment was epigastric bloating, present in $63.3 \%$ of colon cancer patients and in $40 \%$ of individuals with rectal malignancies.

3. Plasma concentrations of enterohormones correlated significantly with the severity of dyspeptic symptoms in colon cancer patients. Specifically, fasting plasma concentrations of ghrelin and motilin correlated inversely with the severity of epigastric bloating, and a positive correlation was found between the plasma level of gastrin and the severity of abdominal dyscomfort.

The pathomechanisms responsible for abnormal secretion of enterohormones in patients with colorectal malignancies are still unknown, and only few previous studies analyzed concentrations of these compounds in individuals with gastrointestinal tumors $[26,29,36,37]$. According to one hypothesis, some substances synthesized within the tumor may interact with the receptors expressed by enteroendocrine cells, which results in a decrease/increase in the synthesis of enterohormones.

Motilin, ghrelin and their receptors belong to the same peptide sub-family. Motilin is released by endocrine cells of the duodenal mucosa to stimulate gastrointestinal motility during fasting. This hormone stimulates hunger contractions in a fasted state and accelerates postprandial gastric emptying [1-5]. In this study, colon cancer patients presented with significantly lower fasting plasma concentrations of motilin than healthy controls. Similar phenomenon was previously reported by Riezzo et al., in breast cancer patients undergoing FEC chemotherapy [24]. However, the proportion of our colon cancer patients who underwent a chemotherapy was relatively low $(56.7 \%)$, markedly smaller than in the case of subjects with rectal malignancies (73.3\%) whose plasma concentrations of motilin were similar as in the asymptomatic controls. Consequently, the hereby documented differences in plasma motilin levels were unlikely related to systemic anticancer treatment. Previously, decreased concentrations of motilin were documented in patients after surgical resection of colorectal and gastric malignancies, before postoperative normalization of gastrointestinal peristalsis. Then, a $200 \%$ increase in the level of this hormone was observed at the time when the peristaltic sounds could be detected stethoscopically, and this effect persisted until the time of initial postoperative stool [25]. Although $76.7 \%$ of colon cancer patients and $83.3 \%$ of individuals with rectal malignancies participating in our study were subjected to radical abdominal procedures, we did not determine plasma concentrations of motilin im- mediately after the surgery. Consequently, an influence of surgical treatment on the values of this parameter determined in our series is unlikely. Elevated concentration of motilin is typical for lower intestinal disorders, rather than for the upper gut pathologies [4]. A decrease in plasma motilin may alter regulation of migration motor complex (MMC) with a gastric phase III (interdigestive migrating contractions) [18, 41, 42]. In our study, the decrease in plasma concentrations of motilin turned out to be associated with greater severity of epigastric bloating in colon cancer patients. Inverse correlations between the fasting concentrations of motilin and ghrelin and the severity of epigastric bloating in colon cancer patients imply that altered secretion of these enterohormones may be associated with delayed emptying of the stomach, resultant stasis and prolonged food retention [12].

Ghrelin is a brain-gut circuit peptide belonging to the ghrelin/motilin-related peptide family [11]. It has a plethora of metabolic and endocrine functions, including control of energy expenditures, gastrointestinal motility, acid and insulin secretion, homeostasis of glucose, and presumably also provides a link between the gut and the central nervous system [3, $9,10,12-19]$. Altered production and secretion of ghrelin has been implicated in many gastrointestinal pathologies, such as inflammatory bowel disease, celiac disease, infectious diseases (e.g. Helicobacter pylori infection), functional disorders (e.g. functional dyspepsia), irritable bowel syndrome, diabetic gastroenteropathy, cachexia and some malignancies $[9,12$, 43-46]. In our study, colon cancer patients presented with significantly lower fasting plasma concentrations of ghrelin than individuals with rectal malignancies. Moreover, we found inverse correlations between the plasma concentrations of ghrelin and motilin in colon cancer patients and the severity of epigastric bloating, a dyspeptic symptom than can be attributed to motor dysfunction of the ileum. Our findings stay in opposition to the data published by Russo et al. and Riezzo et al. According to these authors, dyspeptic symptoms observed in cancer patients during the course of a systemic treatment are associated with elevated plasma concentrations of ghrelin $[24,30]$. However, our colorectal cancer patients were recruited after completing anticancer treatment. Therefore, lower concentrations of ghrelin documented in individuals with colonic malignancies might be associated with presence of persistent inflammatory effusions around the enteric neurons; this might result in visceral hyperactivity or dysautonomia. However, this hypothesis needs to be verified empirically, and thus, an in-depth research is required on this specific aspect of intestinal immune response [47]. In our previously study in this group of patients we observed dysautonomia with sympathetic overactivity, which could disturbing gastrointestinal motility by dysregulation release of enterohormons [48].

Classical gastrins are peptides with 17 or 34 amino acid residues, amidated carboxy terminus and sulphated solitary tyrosine residue. Both the sulphated and unsulphated forms act in the same way on gastrin receptor, but differ in terms of their circulation half-life. Gastrins serve as a growth factor for 
histamine-producing enterochromaffin-like cells, and therefore, indirectly contribute to hydrochloric acid secretion by gastric cells. Non-classical gastrins, i.e. progastrin (precursor of gastrin) and glycine-extended gastrin [20], do not stimulate the acid secretion. These peptides can be found in all cells that express the gastrin gene, including colonic, lung, pancreatic, esophageal and gastric cancer cells $[22,49,50]$. Elevated blood levels of gastrin were shown to correlate positively with pancreatic cancer risk [51].

Autoimmune reactions, Helicobacter pylori infection and acid suppressing drugs may induce chronic atrophic gastritis and resultant hypochlorhydria, which eventually results in enhanced synthesis of gastrin. Presence of gastrin-secreting tumors, gastrinomas, predisposes to hypergastrinemia $[23,36$, 50]. Elevated level of gastrin is currently recognized as a factor involved in pathogenesis of various gastric malignancies, among them gastric cancer [23, 29, 35]. Endogenous hypergastrinemia was also shown to be associated with defects of rectal cell proliferation, and was implicated in development of colonic adenomas and adenocarcinomas [31, 50, 52, 53]. Early stages of colorectal carcinogenesis are associated with activation of gastrin and gastrin/CCK-2 receptor genes within epithelial cells [32]. Prior to anticancer surgery, colorectal cancer patients present with significantly higher plasma levels of gastrin than the controls, but this difference is no longer observed two months thereafter. Interestingly, colonic tumors show markedly higher levels of gastrin precursors (nonclassical gastrins), such as glycine-extended gastrin, than in healthy control [33]. In our present study, patients with colonic and rectal malignancies presented with similar, normal plasma concentrations of gastrin (Figure 1). This might result from previous anticancer treatment, since up to two thirds of the study subjects underwent radical surgical resection prior to being enrolled in this study.

Pancreatic polypeptide is secreted by PP cells of Langerhans islets, as well as by the enteroendocrine cells of the colon and rectum, in response to hunger and satiety signaling from the gut-brain axis [8]. Physiological effects of PP include inhibition of gastric emptying, gallbladder motility and exocrine secretion of the pancreas $[8,54]$. As mentioned previously, patients with metastatic GEPNETs present with markedly elevated levels of PP. Also other conditions, such as older age, diarrhea, abuse of laxatives, gastrointestinal inflammation and chronic renal disease can be associated with overproduction of PP [55]. In contrast, lower levels of this hormone were observed in obese subjects [56]. To the best of our knowledge, none of the previous studies analyzed specific changes in PP concentrations in patients with colorectal malignancies. Our hereby reported findings imply that individuals with colon cancer present with significantly higher plasma levels of PP than patients with rectal malignancies and healthy controls.

A number of previous studies demonstrated that release of PP from the pancreas is under vagal control, and therefore, this enterohormone may serve as a marker of vagal efferent activity $[57,58]$. However, it should be remembered that cancer patients may differ in terms of their stress exposure and emotional responses to oncological diagnosis and treatment, and all these factors may influence their autonomic balance. Since direct measurement of vagal efferent tone is not possible due to rapid degradation of acetylcholine, we used plasma concentration of PP as a surrogate marker of visceral parasympathetic activity. Previous studies showed that patients with ulcerative colitis and Crohn's disease present with significantly elevated fasting plasma concentrations of PP $[59,60]$. This implies that inflammatory bowel diseases may be associated with a shift in the autonomic balance. Colon cancer patients with no doubt present with local inflammation and injuries, resulting both from the presence of tumor and from the surgical treatment. Inflammatory stimulus from the large intestine may substantially alter peripheral neuronal signaling within the brain-gut axis, which eventually results in both peripheral and central sensitization. This, in turn, is reflected by an enhanced afferent neuronal activation [61,62]. As shown recently, brain not only can "detect" peripheral inflammation via afferent vagal fibers, but may also attenuate innate immune activation due to an integrated neural response involving massive activation of vagal efferent fibers. This efferent arm of inflammatory reflex is referred to as "cholinergic anti-inflammatory pathway". Inflammatory reflex is a key homeostatic mechanism. Both cancer itself and anticancer surgery may produce acute or chronic inflammation in the colon and rectum. Impaired autonomic control or direct damage to autonomic fibers may be additional pathophysiological mechanisms contributing to abnormalities of PP release and dysregulation of gastrointestinal motility.

Most colorectal cancer patients participating in our present study did not report any dyspeptic symptoms. The most commonly reported ailment was epigastric bloating, present in $63.3 \%$ of colon cancer patients and in $40 \%$ of individuals with rectal malignancies. In turn, vomiting was of extremely rare evidence ( $10 \%$ of subjects from group A and none from group $\mathrm{B}$ ). The most severe dyspeptic symptoms reported by colon cancer patients included epigastric pain, bloating and abdominal dyscomfort. Epigastric bloating was also the most severe manifestation reported by subjects with rectal malignancies, but prevalence of dyspeptic symptoms in this group was generally very low. To the best of our knowledge, this study is the first to document an association between the severity of dyspeptic symptoms and the plasma concentrations of enterohormones in colorectal cancer patients. Fasting plasma levels of ghrelin and motilin correlated inversely with the severity of epigastric bloating in individuals with colonic malignancies. Moreover, we found a positive correlation between the plasma concentration of gastrin and the severity of epigastric pain reported by patients from this group. In contrast, we did not observe significant correlations between the plasma concentrations of enterohormones and the severity of dyspeptic symptoms in patients with rectal malignancies; however, it should be remembered that prevalence of dyspeptic symptoms 
in this group was very low. Altogether, our findings imply that some dyspeptic symptoms present in colorectal cancer patients may be associated with impaired release of enterohormones.

A principal limitation of this single-center study may be its small sample size (30 patients with colon cancer and 30 subjects with rectal malignancies). Consequently, the hereby presented findings need to be verified in a large group of colorectal cancer patients.

Under physiological conditions, enterohormones do not exert a significant effect on the rectal function, and this seems to be a principal explanation for their normal levels found in patients with malignancies located in this large intestinal segment. Consequently, plasma concentrations of some enterohormones may be specific for anatomical location of primary gastrointestinal malignancy, which points to their potential application as diagnostic markers.

\section{Conclusion}

Colon cancer patients may present with abnormal plasma levels of enterohormones significantly more often than individuals with rectal malignancies. Dysmotility observed in colon cancer patients may result not only from anticancer surgery but also from abnormal production of enterohormones, induced either by neoplastic process or, more likely, by changes within the autonomic nervous system. Unfortunately, lack of published evidence and small size of the hereby examined sample do not allow us to draw any ultimate conclusions in this matter.

Acknowledgements: This study was supported from the specific subsidy of the Ministry of Science and Higher Education for holding research capacity (grant no. K/ZDS/004569). The funding body had no role in this study or its publication. The authors express their gratitude to all patients who participated in this study.

\section{References}

[1] POITRAS P, PEETERS TL. Motilin. Curr Opin Endocrinol Diabetes Obes 2008; 15: 54-57. https://doi.org/10.1097/ MED.0b013e3282f370af

[2] DE SMET B, Mitselos A, Depoortere I. Motilin and ghrelin as prokinetic drug targets. Pharmacol Ther 2009; 123: 207-223. https://doi.org/10.1016/j.pharmthera.2009.04.004

[3] SANGER GJ. Motilin, ghrelin and related neuropeptides as targets for the treatment of GI diseases. Drug Discov Today 2008; 13: 234-239. https://doi.org/10.1016/j.drudis.2007.10.024

[4] SANGER GJ. Motilin receptor neuropharmacology: revised understanding. Curr Opin Pharmacol 2012; 12: 641-646. https://doi.org/10.1016/j.coph.2012.07.012

[5] TAKAHASHI T. Mechanism of interdigestive migrating motor complex. J Neurogastroenterol Motil 2012; 18: 246-257. https://doi.org/10.5056/jnm.2012.18.3.246

[6] ZHANG ZH, WU SD, SU Y, JIN JZ, FAN Y et al. Differences and significance of motilin, vasoactive intestinal peptide and gastrin in blood and gallbladder tissues of patients with gallstones. Hepatobiliary Pancreat Dis Int 2008; 7: 58-64.

[7] CHEY WY, CHANG T. Neural hormonal regulation of exocrine pancreatic secretion. Pancreatology 2001; 1: 320-335. https://doi.org/10.1159/000055831

[8] ADAMSKA E, OSTROWSKA L, GORSKA M, KRETOWSKI A. The role of gastrointestinal hormones in the pathogenesis of obesity and type 2 diabetes. Prz Gastroenterol 2014; 9: 69-76. https://doi.org/10.5114/pg.2014.42498

[9] EL-SALHY M. Ghrelin in gastrointestinal diseases and disorders: a possible role in the pathophysiology and clinical implications (review). Int J Mol Med 2009; 24: 727-732. https://doi.org/10.3892/ijmm 00000285

[10] FUJITSUKA N, ASAKAWA A, AMITANI H, FUJIMIYA M, INUI A. Ghrelin and gastrointestinal movement. Methods Enzymol 2012; 514: 289-301. https://doi.org/10.1016/B9780-12-381272-8.00018-0

[11] CHEN CY, TSAI CY. Ghrelin and motilin in the gastrointestinal system. Curr Pharm Des 2012; 18: 4755-4765. https:// doi.org/10.2174/138161212803216915

[12] CHEUNG CK, WU JC. Role of ghrelin in the pathophysiology of gastrointestinal disease. Gut Liver 2013; 7: 505-512. https:// doi.org/10.5009/gnl.2013.7.5.505

[13] MAJCHRZAK K, SZYSZKO K, PAWŁOWSKI KM, MOTYL T, KROL M. A role of ghrelin in cancerogenesis. Pol J Vet Sci 2012; 15: 189-197. https://doi.org/10.2478/v10181-011-0133$\underline{5}$

[14] PEETERS TL. Ghrelin and the gut. Endocr Dev 2013; 25: 41-48. https://doi.org/10.1159/000346051

[15] PEETERS TL. Central and peripheral mechanisms by which ghrelin regulates gut motility. J Physiol Pharmacol 2003; 54 Suppl 4: 95-103.

[16] VU JP, WANG HS, GERMANO PM, PISEGNA JR. Ghrelin in neuroendocrine tumors. Peptides 2011; 32: 2340-2347. https://doi.org/10.1016/j.peptides.2011.10.006

[17] RAU TT, SONST A, ROGLER A, BURNAT G, NEUMANN $\mathrm{H}$ et al. Gastrin mediated down regulation of ghrelin and its pathophysiological role in atrophic gastritis. J Physiol Pharmacol 2013; 64: 719-725.

[18] SANGER GJ, FURNESS JB. Ghrelin and motilin receptors as drug targets for gastrointestinal disorders. Nat Rev Gastroenterol Hepatol 2016; 13: 38-48.

[19] NIKOLOPOULOS D, THEOCHARIS S, KOURAKLIS G. Ghrelin: a potential therapeutic target for cancer. Regul Pept 2010; 163: 7-17. https://doi.org/10.1016/j.regpep.2010.03.011

[20] DIMALINE R, VARRO A. Novel roles of gastrin. J Physiol 2014; 592: 2951-2958. https://doi.org/10.1113/ jphysiol.2014.272435

[21] SMITH JP, FONKOUA LK, MOODY TW. The role of gastrin and CCK receptors in pancreatic cancer and other malignancies. Int J Biol Sci 2016; 12: 283-291. https://doi.org/10.7150/ ijbs. 14952

[22] DOCKRAY G, DIMALINE R, VARRO A. Gastrin: old hormone, new functions. Pflugers Arch 2005; 449: 344-355. https://doi.org/10.1007/s00424-004-1347-5

[23] BURKITT MD, VARRO A, PRITCHARD DM. Importance of gastrin in the pathogenesis and treatment of gastric tumors. 
World J Gastroenterol 2009; 15: 1-16. https://doi.org/10.3748/ wjg. 15.1

[24] RIEZZO G, CLEMENTE C, LINSALATA M, D'ATTOMA B, ORLANDO A et al. Gut peptide profile and chemotherapyassociated dyspepsia syndrome in patients with breast cancer undergoing FEC60 chemotherapy. Anticancer Res 2013; 3: 4951-4957.

[25] FUJIMOTO S, MIYAZAKI M, ISHIGAMI H, TSURUTA Y, OKUI K. Plasma motilin levels in patients with abdominal surgery. Acta Chir Scand 1982; 148: 33-37.

[26] ZHANG Q, YU JC, KANG WM, KE MY, QAIN JM. Changes of serum gastrin, plasma motilin, and gastric motility in gastric cancer patients after subtotal gastrectomy. Zhongguo Yi Xue Ke Xue Yan Xue Bao 2008; 30: 334-337.

[27] WALTER T, CHARDON L, CHOPIN-LALY X, RAVEROT $\mathrm{V}, \mathrm{CAFFIN} \mathrm{AG}$ et al. Is the combination of chromogranin A and pancreatic polypeptide serum determinations of interest in the diagnosis and follow-up of gastro-entero-pancreatic neuroendocrine tumours? Eur J Cancer 2012; 48: 1766-1773. https://doi.org/10.1016/j.ejca.2011.11.005

[28] NIKOLOPOULOS D, THEOCHARIS S, KOURAKLIS G. Ghrelin's role on gastrointestinal tract cancer. Surg Oncol 2010; 19: e2-e10. https://doi.org/10.1016/j.suronc.2009.02.011

[29] ZUB-POKROWIECKA A, REMBIASZ K, KONTUREK PC, BUDZYŃSKI A, KONTUREK SJ et al. Ghrelin and gastrin in advanced gastric cancer before and after gastrectomy. World J Gastroenterol 2011; 17: 449-458. https://doi.org/10.3748/ wjg.v17.i4.449

[30] RUSSO F, LINSALATA M, CLEMENTE C, DAATTOMA B, ORLANDO A et al. The effects of fluorouracil, epirubicin, and cyclophosphamide (FEC60) on the intestinal barrier function and gut peptides in breast cancer patients: an observational study. BMC Cancer 2013; 13: 56. https://doi.org/10.1186/14712407-13-56

[31] SMITH AM, WATSON SA. Review article: gastrin and colorectal cancer. Aliment Pharmacol Ther 2000; 14: 1231-1247. https://doi.org/10.1046/j.1365-2036.2000.00842.x

[32] TAKHAR AS, EREMIN O, WATSON SA. The role of gastrin in colorectal carcinogenesis. Surgeon 2004; 2: 251-257. https:// doi.org/10.1016/S1479-666X(04)80093-3

[33] PENMAN ID, MC COLL KE. Gastrin and colorectal cancer: where now? Eur J Gastroenterol Hepatol 1998; 10: 285-288. https://doi.org/10.1097/00042737-199804000-00002

[34] ALY A, SHULKES A, BALDWIN GS. Gastrins, cholecystokinins and gastrointestinal cancer. Biochim Biophys Acta 2004; 1704: 1-10. https://doi.org/10.1016/j.bbcan.2004.01.004

[35] SHAO Y, SUN K, XU W, LI XL, SHEN H et al. Helicobacter pylori infection, gastrin and cyclooxygenase- 2 in gastric carcinogenesis. World J Gastroenterol 2014; 20: 12860-12873. https://doi.org/10.3748/wig.v20.i36.12860

[36] FOSSMARK R, SAGATUN L, NORDRUM IS, SANDVIK AK, WALDUM HL. Hypergastrinemia is associated with adenocarcinomas in the gastric corpus and shorter patient survival. APMIS 2015; 123: 509-514. https://doi.org/10.1111/ apm. 12380

[37] BOMBSKI G, GĄSIOROWSKA A, ORSZULAK-MICHALAK D, NENEMAN B, KOTYNIA J et al. Elevated plasma gastrin, CEA, and CA 19-9 levels decrease after colorectal cancer resection. Int J Colorectal Dis 2003; 18: 148-152.

[38] SELGRAD M, BORNSCHEIN J, KANDULSKI A, HILLE C, WEIGT $J$ et al. Helicobacter pylori but not gastrin is associated with the development of colonic neoplasms. Int J Cancer 2014; 135: 1127-1131. https://doi.org/10.1002/ijc.28758

[39] LAMBERTS R, WARTENBERG T, CREUTZFELDT W. Role of circulating gastrin in colorectal adenomas and carcinomas. Digestion 1999; 60: 101-109. https://doi. org/10.1159/000007634

[40] NIV Y, HEIZELRACHT N, LAMPRECHT SA, SPERBER AD, FRASER GM et al. Gastrin levels in colorectal cancer. Isr J Med Sci 1997; 33: 186-189.

[41] DELOOSE E, VOS R, CORSETTI M, DEPOORTERE I, TACK J. Endogenous motilin, but not ghrelin plasma levels fluctuate in accordance with gastric phase III activity of the migrating motor complex in man. Neurogastroenterol Motil 2015; 27: 63-71. https://doi.org/10.1111/nmo.12470

[42] OHNO T, MOCHIKI E, KUWANO H. The roles of motilin and ghrelin in gastrointestinal motility. Int J Pept 2010; doi: 10.1155/2010/820794. https://doi.org/10.1155/2010/820794

[43] SJOLUND K, EKMAN R, WIERUP N. Covariation of plasma ghrelin and motilin in irritable bowel syndrome. Peptides 2010; 31: 1109-1112. https://doi.org/10.1016/j. peptides.2010.03.021

[44] OGISO K, ASAKAWA A, AMITANI H, INUI A. Ghrelin: a gut hormonal basis of motility regulation and functional dyspepsia. J Gastroenterol Hepatol 2011; 26 Suppl 3: 67-72. https://doi.org/10.1111/j.1440-1746.2011.06630.x

[45] STRASSER F. Clinical application of ghrelin. Curr Pharm Des 2012; 18: 4800-4812. https://doi. org/10.2174/138161212803216870

[46] KHOO J, RAYNER CK, FEINLE-BISSET C, JONES KL, HOROWITZ H. Gastrointestinal hormones dysfunction in gastroparesis and functional dyspepsia. Neurogastroenterol Motil 2013; 22: 1270-1278. https://doi.org/10.1111/j.13652982.2010.01609.x

[47] AATAR D, PATEL K, TAUB DD. The effects of ghrelin on inflammation and the immune system. Mol Cell Endocrinol 2011; 340: 44-58. https://doi.org/10.1016/j.mce.2011.04.019

[48] ZYGULSKA A, FURGAŁA A, KRZEMIENIECKI K, THOR P. Estimation of autonomic nervous system activity by heart rate and blood pressure variability in patients with gastric and colorectal cancer. Preliminary study. Annals of Oncology 2015; 26 (Supplement 4): iv1-iv100. https://doi.org/10.1093/ annonc/mdv233.160

[49] SINGH P, WU H, CLARK C, OWLIA A. Annexin II binds progastrin and gastrin-like peptides, and mediates growth factor effects of autocrine and exogenous gastrins on colon cancer and intestinal epithelial cells. Oncogene 2007; 26: 425-440. https://doi.org/10.1038/sj.onc.1209798

[50] COPPS J, MURPHY RF, LOVAS S. The production and role of gastrin-17 and gastrin-17-gly in gastrointestinal cancers. Protein Pept Lett 2009; 16: 1504-1518. https://doi. org/10.2174/092986609789839269

[51] SMITH JP, FONKOUA LK, MOODY TW. The role of gastrin and CCK receptors in pancreatic cancer and other malignan- 
cies. Int J Biol Sci 2016; 12: 283-291. https://doi.org/10.7150/ ijbs. 14952

[52] WATSON SA, MORRIS TM, MC WILLIAMS DF, HARRIS J, EVANS $S$ et al. Potential role of endocrine gastrin in the colonic adenoma carcinoma sequence. Br J Cancer 2002; 87: 567-573. https://doi.org/10.1038/sj.bjc.6600509

[53] RENGA M, BRANDI G, PAGANELLI GM, CALABRESE C, PAPA $S$ et al. Rectal cell proliferation and colon cancer risk in patients with hypergastrinaemia. Gut 41:330-332. https:// doi.org/10.1136/gut.41.3.330

[54] SLIWINSKA-MOSSON M, BOROWIECKA K, MILNEROWICZ H. Neuropeptides Y,YY, PP and their clinical significance. Postepy Hig Med Dosw 2013; 67: 631-636. https://doi. org/10.5604/17322693.1058890

[55] VINNIK AI, SILVA MP, WOLTERING EA, GO VL, WARNER R et al. Biochemical testing for neuroendocrine tumors. Pancreas 2009; 38: 876-889. https://doi.org/10.1097/ MPA.0b013e3181bc0e77

[56] LASSMANN V, VAGUE P, VIALETTES B, SIMON MC. Low plasma levels of pancreatic polypeptide in obesity. Diabetes 1980; 29: 428-430. https://doi.org/10.2337/diab.29.6.428
[57] SCHWARTZ TW. Pancreatic polypeptide: a hormone under vagal control. Gastroenterology, 1983; 85: 1411-1425.

[58] BATTERHAM RL, Le ROUX CW, COHEN MA, PARK AJ, ELLIS SM et al. Pancreatic polypeptide reduces appetite and food intake in humans. J Clin Endocrinol Metab. 2003; 88: 3989-3992. https://doi.org/10.1210/jc.2003-030630

[59] LINGREN S, LILJA B, ROSEN I, SUNDKVIST G. Disturbed autonomic nerve function in patients with Crohn's disease. Scand J Gastroenterol 1991; 26: 361-366. https://doi. org/10.3109/00365529108996495

[60] LINGREN S, STEWENIUS J, SJOLUND K, LILJA B, SUNDKVIST G. Autonomic vagal nerve dysfunction in patients with ulcerative colitis. Scand J Gastroenterol 1993; 28: 638-642. https://doi.org/10.3109/00365529309096103

[61] BONAZ BL, BERNSTEIN CN. Brain-gut interactions in inflammatory bowel disease. Gastroenetrology 2013; 144: 36-49. https://doi.org/10.1053/j.gastro.2012.10.003

[62] HUSTON JM. The vagus nerve and the inflammatory reflex: wandering on a new treatment paradigm for systemic inflammation and sepsis. Surg Infect 2012; 13: 187-193. https://doi. org/10.1089/sur.2012.126 


\section{Supplementary Table 1}

Questionnaire of dyspeptic symptoms.

\begin{tabular}{||l|l|l|l|l|l||}
\hline Dyspeptic symptoms scale (3 months) & 1 & 2 & 3 & 4 & 5 \\
\hline 1. epigastralgia & & & & & \\
\hline 2. a painful sensation of epigastric region & & & & & \\
\hline 3. heartburn & & & & & \\
\hline 4. regurgitation & & & & & \\
\hline 5. early feeling of satiety & & & & & \\
\hline 6. feeling of food retention in stomach & & & & & \\
\hline 7. bloating in epigastric region & & & & & \\
\hline 8. nausea & & & & & \\
\hline 9. vomiting & \\
\hline 10. loss of appetite & & & & & \\
\hline
\end{tabular}

Intensification of symptoms: 0 - absent, 1- incidental, 2 - seldom, 3 - often, 4 - almost always, 5 - constant. 